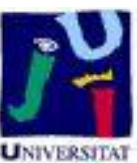

Título artículo / Títol article: Top executive pay in Spanish banking system

\author{
Autores / Autors \\ Ferrero Ferrero, Idoya ; Fernández Izquierdo, María \\ Ángeles ; Muñoz Torres, María Jesús
}

Revista:

Versión / Versió:

Cita bibliográfica / Cita bibliogràfica (ISO 690):
Journal of Management \& Organization Volume 20, Issue 03, May 2014

Preprint de l'autor

FERRERO-FERRERO, Idoya; FERNÁNDEZ-IZQUIERDO, María Ángeles; MUÑOZ-TORRES, María Jesús. Top executive pay in Spanish banking system. Journal of Management \& Organization, 2014, 20.03: 333-347.

url Repositori UJI: http://hdl.handle.net/10234/129165 


\title{
Top Executive Pay in Spanish Banking System
}

\author{
Dr. Idoya Ferrero Ferrero* \\ ferrero@cofin.uji.es \\ Professor María Ángeles Fernández Izquierdo \\ afernand@cofin.uji.es \\ Professor María Jesús Muñoz Torres \\ munoz@cofin.uji.es \\ Finance and Accounting Department \\ Universitat Jaume I of Castellón \\ Castellón de la Plana, Spain
}

\begin{abstract}
This study examines consistency between compensation systems and corporate performance. The main purpose is to analyse how the performance has affected the shortterm executive pay in Spanish banking system during the period 2004-2008. The main results reveal that pay-performance sensitivity is asymmetrical regarding the sign of the variation of the performance, since the pay-performance sensitivity is greater when the the pay-performance sensitivity is positive than when the variation of the results is negative. This finding is consistent with the managerial power theory and calls into question the role of the pay-performance incentives to align interest of executives and shareholders.
\end{abstract}

Keywords: Top executive pay, performance, Spanish banking system, financial crisis, corporate governance.

\footnotetext{
* Correspondingh author. Contact information: e-mail ferrero@cofin.uji.es, phone +34 964387 143, fax +34964728565
} 


\section{INTRODUCTION}

Several developments over the past two decades have major implications for corporate governance, which have become an important issue for academics, professionals, legislators, and international agencies. Many corporate scandals in various developed nations have been characterized by weak mechanisms of corporate governance. This has motivated research and analysis of the relationship between good corporate governance and firm performance.

From a theoretical perspective, several models argue that a proper governance structure reduces agency problems and conflicts of interest, generating value for the organization. However, the global financial and economic crisis has highlighted weaknesses in corporate governance, especially in the financial sector (Hilb, 2010; Smallman, McDonald, \& Mueller, 2010). In this context, an international debate has arisen on the effectiveness of the executive incentive system to ensure that executives make decisions consistent with the shareholders' interest and to achieve long-term sustainability performance (Galbreath, 2012). In this respect, the European Commission (EC) (2010) suggests that the inappropriate compensation system established in the top executives has negatively affected the firms' long-term viability and, consequently in the shareholders' firm value.

In the last two decades, the relevance of variable pay schemes has considerably increased. Theoretically, the purpose of variable pay should be to align the interests of managers with the owners. However, the European Corporate Governance Forum remarks that "experience has shown that variable pay schemes have become increasingly complex and that in certain instances this has lead to excessive remuneration and manipulation" $(2009, \mathrm{p}$. 1). In this regard, the EC also highlights that "the remuneration policies in the financial sector, based on short-terms profits without taking into account the corresponding risks, contributed to the financial crisis" (2010, p. 10). 
The widespread public attention on executive compensation in financial sector suggests that the design of the compensation structure deserves closer scrutiny. Empirical studies (Adams \& Mehran, 2003; John \& Qian, 2003; Kaplan \& Rauh, 2010) have found evidence that the structure and evolution of executive compensation differ between financial and nonfinancial industries, which might be due to differences in the investment opportunities and the regulation between financial and non-financial industries. Nonetheless, the literature focused on financial firms and aspects of corporate governance, such as executive compensation, is still limited (Aebi, Sabato, \& Schmid, 2012). This study attempts to contribute to the compensation research by providing an analysis on executive compensation and corporate performance in the financial sector.

Recent academic studies have examined whether flawed compensation structures in financial firms contributed to the most recent financial crisis (Faulkender, Kadyrzhanova, Prabhala, \& Senbet, 2010). However, to date there is no consensus whether compensation policies were a critical driver of the financial crisis. Fahlenbrach and Stulz (2011) find that no evidence exists that banks with a better alignment of the executive's interests with those of the shareholders had higher stock returns during the crisis. Erkens, Hung, and Matos (2009) show that CEO (Chief Executive Officer) compensation packages that rely more on annual bonuses, and less on long-term equitiy-based compensation, are associated with greater losses in financial firms during the crisis and higher risk taking before the crisis. Hau and Thum (2009) find that higher executive compensation is positively associated with bank losses. Minnick, Unal, and Yang (2011) present evidence that banks with higher pay-performance sensitivity have significantly higher stock returns around the time of acquisitions announcements and align better the interests of the CEO with the interests of shareholders. These mixed results suggest that more rigorous investigation of compensation structures at financial sector is clearly needed. 
This study extends the previous empirical evidence on compensation policy at financial firms focusing on the Spanish banking system, which has been in the brink of the collapse. In Spain, bank's executives have long been criticized for their high compensation received in companies with poor performance. The depth of the economic crisis in the Spanish financial institutions and the intervention and nationalization of several banking institutions (Royo, 2012) are incoherent with the millionaire salaries and severance packages received by their executive managers. This fact raises questions about the influence of executives to define their own incentive schemes. In this context, sporadic studies have explored the relationship between the characteristics of board of directors and the level and structure of compensations (Manzaneque, Merino, \& Banegas, 2011) and between the economic performance and the ownership form of the bank (Crespí, García-Cestona, \& Salas, 2004; Grifell-Tatjé, 2011) . However, research on the consistency between executive compensation and the corporate performance requires further development.

This study fills in this gap and examines how corporate performance has affected the executive pay in the Spanish banking system during the period 2004-2008. This work follows Jensen and Murphy (1990) and defines the relation between executive pay and performance as "pay-performance sensitivity" which shows how compensation varies with measured performance. Consistent with the managerial power theory (Bebchuk \& Fried, 2004; Bebchuk, Fried, \& Walker, 2002), this study casts doubt on a linear relationship between executive pay and performance and aims to examine the pay-performance sensitivity depending on the sign of variation in bank performance. This study focuses on short executive pay (SEP), which does not include post-employment benefits or equity compensations benefits with the aim of providing robust results given the peculiarities of the financial institutions included in the sample and the limitation of public information, as well as avoiding that the research question could be biased by the possible effect of non-linear 
association between stock options and firm performance (Devers, Cannella, Reilly, \& Yoder, 2007; Hanlon, Rajgopal, \& Shevlin, 2003).

This study contributes to research in several ways. First, it expands the managerial power theory because it introduces the variation of corporate performance and the ownership type as new factors in the general explanation of this theory. Second, it provides new empirical evidence related to a non-linear relationship of the pay-performance sensitivity depending on the sign of the variation of the performance in Spanish banking system. Third, this study uses a rigorous methodology that is consistent with the presence of unobserved heterogeneity in each institution and controls endogeneity problems. Fourth, it advances the debate about whether the structure of executive compensation aligned the interest of managers and shareholders before and during the most recent financial crisis. Fifth it identifies new avenues for future research to advance the understanding of the relation between executive compensation and corporate performance.

This work is divided into five sections. After this introduction this study presents a literature review and the hypotheses. The third section includes information on the sample, variables, and the methodology used in estimating the models. Section four presents the results and the final section offers the main conclusions.

\section{LITERATURE REVIEW AND HYPOTHESES}

The relationship between executive compensation and company performance has been widely analysed from theoretical and empirical perspectives. Agency theory (Fama \& Jensen, 1983; Jensen \& Meckling, 1976) argues that the incentives of managers can be aligned with the objectives of the shareholders through the design of a contract that links the compensations of executives with business results (Evans \& Weir, 1995). However, Zingales (1998) remarks that it is impossible to perfect a priori contract that fairly shares quasi-rents generated by a 
company to all its stakeholders, including executives and shareholders, and this quasi-rents will be captured by those groups with the most bargaining power.

This controversy is extended to empirical works (Sánchez-Marín, Baixauli-Soler, LucasPérez, \& 2010). On the one hand, most of the studies have revealed a statistically significant positive relationship between changes in the wealth of shareholders and the compensations of executives (Conyon \& Schwalbach, 2000; Jensen \& Murphy, 1990; Lee, Lee, \& Wu, 2010; Murphy, 1999) and this relationship is consistent with agency theory. On the other hand, other studies offer evidence for the existence of a negative or negligible relationship between performance and the compensations of executives, concluding that managers put its own interests before the aims of the company owners (Core, Holthausen, \& Larcker, 1999; Duffhues \& Kabir, 2008).

Devers et al. (2007) argue that the mixed findings that pervade the field may result from a narrow focus that failed to incorporate other theoretical perspectives and methodologies. Recent theoretical developments have expanded agency theory explanations of the incentive alignment construct (Nyberg, Fulmer, Gerhart, \& Carpenter, 2010). In this vein, managerial power theory states that boards of directors approve compensation schemes that deviate from optimal contracting, since directors are subject to influence by management or are ineffective in overseeing managerial behaviour. As a result, top executives may camouflage or extract corporate rents by means of inefficient pay structures which are more in the interest of executives than shareholders. However, the evidence regarding the impact of CEO power on their compensations is insufficient and requires further studies (Tien, Chen, \& Chuang, 2013).

Accordingly to the argument that top executives generally prefer a higher level of compensation that is less contingent upon performance, managerial power theory states that 
top executives have influence over the board of directors to approve compensation contracts that are more favorable to receive higher levels of pay and less sensitive to performance (Shin, 2013). In a recent meta-analysis (Van Essen, Otten, \& Carberry, 2012) on existing empirical studies focused on the managerial power theory, Van Essen et al. (2012) conclude that top executives with greater power tend to receive higher levels of total pay and total compensation. However, the authors find that the results for performance-pay sensitivities provide less support for managerial power theory. Van Essen et al. (2012) explain that this unexpected finding could be due to the existence of a non-linear relationship between CEO pay and performance, since the number of studies investigating non-linear relationships is relatively limited.

Recently, few scholars (Canarella \& Nourayi, 2008; Leone, Shuang, \& Zimmerman, 2006) have challenged the linear relationship between executive compensation and performance, and have examined a non-linear and asymmetric influence of performance on compensations, depending on whether the company is profitable or not. Yet no theoretical or empirical consensus exists on how this asymmetry is reflected. Canarella and Nourayi (2008) conclude that, from an accounting approach, a positive return by a company has a positive influence, although the executives are rewarded to greater extent for a positive return than they are penalized for a negative return. Leone et al. (2006) suggest that the salaries of managers are more sensitive to losses than to expected but unrealised profits. The authors state that these results are in line with the theoretical approach of the optimal contract. This approach is based on the idea that the implementation of an optimal contract reduces agency costs in relation to the expropriation of income from shareholders by the executives. Therefore, if the compensations of executives were more sensitive to expected profits than losses (the opposite case to that evidenced) then the executives may be rewarded for profits 
that do not finally appear. If the compensation were not reimbursed then an ex post settling up problem would be created.

While the limited previous studies have analysed the asymmetric influence of firm performance on executive compensations, depending on whether the company is profitable or not, none of these has considered a non-linear relationship of the pay-performance sensitivity depending on the variation of corporate performance. This study sets its aim in this underdeveloped area of investigation in order to advance the debate about whether the structure of executive compensation aligned the interest of managers and shareholders before and during the most recent financial crisis.

The financial crisis has revealed weaknesses in the pay-setting process in the financial institutions since compensation schemes did not help mitigate agency problems and failed to closely align the interests of executives and shareholders (Faulkender et al. 2010). According to this argument, this study expands the explanation of the managerial power theory. This study states that whether the board of directors does not effectively oversee the design of incentive systems, the managers will have important influence over the compensation arrangements in order to serve their own interests rather than shareholders. In this case, it is expected that the pay-performance sensitivity is greater when the variation in the corporate performance is positive than when the variation is negative. Consequently, this study tests the existence of a non-linear relationship that is asymmetrical in terms of pay-performance sensitivity to the sign of variation in bank performance. Accordingly, the following hypothesis is presented:

$H_{01}$ : The short executive pay presents an asymmetric positive relationship with performance, since the short executive pay is more sensitivity with respect performance when 
the variation in performance is positive than when the variation in performance is negative with respect the previous year.

In this context, several empirical studies have estimated an econometric model where the explanatory variables are contemporary related with the explanatory variables. However, the assumption of not considering the dynamic behaviour of economic variables has been widely refuted. It is argued that the relationship between compensations and company profits is not only contemporary (Duffhues \& Kabir, 2008; Murphy, 1999). Moreover in the short-term executive pay is taken into account the profit-sharing and bonuses if they are paid within 12 months of the end of the period. Therefore, the following hypothesis is proposed:

$H_{02}$ : The short executive pay is influenced by current performance and the performance of the previous year.

It is also argued that the executive compensation is persistent over time, which makes this variable dependent on its own past. Canarella and Nourayi (2008) and Lilling (2006) incorporated the first lag of the dependent variable in the equation and concluded that there was a positive and significant relation between the variable and the first lag. Consequently, the following hypothesis is expected:

$H_{03}$ : The contemporary executive pay is positively related to pay of the previous period.

In the Spanish banking system there are important differences in the corporate governance between commercial banks and savings banks. Commercial banks are privately owned institutions with a concentrated ownership structure and with a strong shareholder control (shareholder-oriented approach). Spanish savings banks are commercial non-profit organisations (Hansmann, 1996), which have no owners or shareholders and are controlled by multiple interest groups: local and regional governments, employees, depositors and their 
founding entities (stakeholder-oriented approach). Several authors (Crespí, et al. 2004; García-Marco \& Robles-Fernández, 2008; Sagarra, Mar-Molinero, \& García-Cestona, 2013), have argued that the dispersed ownership structure and the lack of shareholder control of the savings banks could give managers more freedom of action and leave much room for abuse and corrupt practices. Therefore, according to managerial power theory, executive managers of Spanish savings banks have more power over the board of directors to negotiate for higher pay than executive managers of commercial banks. In this case, the following hypothesis is suggested:

$H_{04}:$ The short executive pay in the Spanish savings banks is higher than the commercial banks.

\section{SAMPLE, VARIABLES OF THE MODEL, AND METHODOLOGY}

\section{Sample}

The sample includes banks and savings banks issuing securities admitted to trading on regulated markets from Spain for the period 2004-2008. According to the Spanish Securities and Investments Board, 22 banks and 42 savings banks are required to publish an annual corporate governance report $(\mathrm{CNMV}, 2008)$. Credit cooperatives were not considered because of their low market share in the Spanish banking sector.

Data for the top executive pay has been extracted from the annual accounts and the annual corporate governance report for each bank. Additionally, the financial information from 2000 to 2007 for each bank has been obtained from Intertell database. The financial information for the year 2008 has been gathered from the annual accounts published by Spanish Securities and Investments Board. However, this information was collected until 
May 2009 and in this date 11 banks had not yet published their accounts, therefore, some information is missing.

Insert table 1 about here

The available information was used to construct an unbalanced panel of 61 banks (22 banks and 39 savings banks), which represents approximately 95\% of the sample. After removing those financial institutions that did not have all the data and establishing that it is needed five years of continuous data, the final sample was a balanced panel of 195 observations for 9 banks and 30 savings banks, which represents $61 \%$ of sample. Table 1 shows the descriptive statistics of the data included in each panel. In general, the data analysed does not show a normal distribution. Variables such as SEP and total assets are characterized by positively asymmetrical distribution and high kurtosis.

\section{Variables}

This article uses the panel data methodology since this study has the cross-sectional and timeseries data available. The models use the subscript ' $i$ ' ' $t$ ' to refer to a given variable corresponding to the $\mathrm{i}$-th bank at time t. Following previous studies (Barontini \& Bozzi, 2011; Canarella \& Nourayi, 2008; Duffhues \& Kabir, 2008; Lilling, 2006; Perry \& Zenner, 2001; Shiwakoti, 2012; Vander Bauwhede, 2009), the neperian logarithm of executive compensation $\left(\ln \left(S E P_{\mathrm{it}}\right)\right)$ is used as the dependent variable of the model. As presented above, the executive compensation variable is measured by SEP. This variable includes the following concepts: wages, salaries and social security contributions, paid annual leave and paid sick leave, profit-sharing and bonuses (if payable within 12 months of the end of the period) and non-monetary benefits (such as medical care, housing, cars and free or subsidized goods or services) for current executives (IAS 19, 2003, pp.138). Following this definition, 
SEP does not include post-employment benefits or equity compensation benefits for four reasons. The first reason is to homogenise the variable regarding executive compensation, since the savings banks are not listing on the stock market and therefore the stock options are not applicable. Moreover, the SEP represents a high percentage (83\%) over the total executive pay. The third reason is due to the limitation in the public information available about long-term executive pay since the $37 \%$ of the analysed sample does not mention the long term executive pay in their annual accounts. The fourth reason is not to consider the possible effect of non-linear associations between stock options grants and firm performance (Hanlon et al. 2003; Devers et al. 2007), since the inclusion of the equity compensations in the applicable institutions (banks represents $23 \%$ of the sample) could bias the results of this study.

An explanatory variables included in the model is the performance of the bank $\left(P_{i t}\right)$. This variable can be used as a proxy for the operating margin per unit of total assets, or for aftertax profits per unit of asset; although the latter would mean taking into account operating profits, as well as extraordinary profits, or losses and discretionary provisions. Following Core et al. (1999), Duffhues and Kabir (2008), Ianotta, Nocera, and Sironi (2007) and the proxy used for the performance variable for each bank is the operating margin ratio divided by total assets, because this margin is the most faithfully reflects the performance of a bank. This study uses accounting ratios-based measures of performance because market-based performance measures cannot be applied in the majority institutions of the sample. Spanish savings banks do not issue shares, since they do not have owners or shareholders. Additionally, accounting-based measures reflect current performance, whereas market-based measures reflect investor's perceptions of future value (Devers et al., 2007). 
Another variable is the "SUBINDUSTRY it" which is defined by the two different ownership types examined in this study. Following previous studies (Crespí, et al. 2004; García-Marco and Robles-Fernández, 2008), a dummy variable is used to reflect the differences between the Spanish savings banks and commercial banks. This dummy variable takes a value of 1 for Spanish savings banks and 0 for commercial banks.

Despite the numerous recommendations (Comisión Conthe, 2006; EC, 2009) to increase the transparency of compensations for executives and directors as a measure against excessive salaries, the public information about compensations of executive remains partial. The salaries received by a bank's key personnel are published as a global amount. In addition to this limitation in the information, the banks do not follow uniform criteria regarding the posts listed, nor do they list the roles played by key personnel. Furthermore, comparison is made more difficult because this variable shows a wide range in the sample used. Therefore, given the public information available, the dependent variable has been calculated dividing SEP by the number of executives that the bank lists as key personnel. In this regard, with the aim of controlling the fact that the average compensations of executives decrease as the number of key personnel increase, this study has included in the model the number of key personnel $\left(\mathrm{NE}_{\mathrm{it}}\right)$. Moreover, the differences in compensations among key personnel are lower in posts with lesser responsibilities and may even reach a minimum; therefore, this study has also introduced the squared in the number of executives $\left(\mathrm{NE}_{\mathrm{it}}^{2}\right)$ in the model.

With respect to other control variables, this study follows Andres and Vallelado (2008) and employs two measures related to banking business: the neperian logarithm of total assets $\left(\mathrm{TA}_{\mathrm{it}}\right)$ as an indicator of size; and the volume of credits granted per unit of total assets $\left(\right.$ CREDIT $\left._{\text {it }}\right)$ as a proxy of banking activity. The efficiency of risk management is also included in the model. To this end, this study uses a dummy variable indicator of banks 
authorised by the Bank of Spain (MA_RISK ${ }_{i t}$ ) to implement the 'internal ratings-based' approach (IRB), because these banks, according to Basel II (BCBS, 2004), must have advanced management systems and risk measurement in place. Additionally, this study uses dummy variables for different years $\left(\mathrm{YEAR}_{\mathrm{t}}\right)$.

\section{Methodology}

As indicated by Gibbons and Murphy (1990) agency theory suggests that the compensations of executives are related to performance in absolute or relative terms. This work has started from equation (1), which is a widely used model in the literature (Jensen \& Murphy, 1990; Murphy, 1985) that links executive compensation with the performance of a bank.

$$
\ln (S E P)_{i, t}=\beta_{0}+\beta_{1} \cdot P_{i, t}+\beta_{2} \cdot P_{i, t-1}+\sum_{j=1}^{J} \lambda_{j} \cdot V \cdot C O N T R O L_{i, t}+u_{i, t}
$$

Model (1) from a time dimension focus includes the first lag corresponding to an exogenous variable. This feature does not breach the basic hypothesis of the general linear model because all the explanatory variables remain deterministic. However, the crosssectional and temporal nature of data means that consideration must be given to the existence of latent unobservable effects specific to each individual. If these effects are not considered explicitly in the model, the estimated coefficients of the explanatory variables will be biased, as they reflect some of the unobservable effects of each individual (Novales, 2000).

$$
\begin{aligned}
\ln \left(\operatorname{SEP}_{i, t}\right) & =\beta_{0}+\beta_{1} \cdot P_{i, t}+\beta_{2} \cdot P_{i, t-1}+\beta_{3} \cdot \operatorname{SUBINDUSTRY_{i,t}} \\
& +\beta_{4} \cdot N E_{i, t}+\beta_{5} \cdot N E_{i, t}^{2}+\beta_{6} \cdot \ln (A T)_{i, t}+\beta_{7} \cdot \text { CREDIT }_{i, t} \\
& +\beta_{8} \cdot M A_{-} \operatorname{RISK}_{i, t}+\sum_{J=1}^{4} \lambda_{J} \cdot Y E A R_{t}+\eta_{i}+v_{i t}
\end{aligned}
$$

Equation (2) specifies the general econometric model of this work, where the error term is divided $\left(u_{i, t}\right)$ into two components: the individual effects $\left(\eta_{i}\right)$ which include the effect of 
non-observable variables in each bank, constant over time, and the stochastic disturbance. Traditionally, two transformations have been used of equation (2) to eliminate the problem of unobserved heterogeneity: deviations from the group averages (within estimator) and time differences (Gibbons \& Murphy, 1990; Perry \& Zenner, 2001).

Most studies assume that the explanatory variables of the model are exogenous as their values are taken as given, and so remain uninfluenced by the variable to be explained. However, in our model this hypothesis runs contrary to the empirical evidence, because from an accounting point of view, bank profit is affected by the salary costs of all employees (temporary and permanent). In this regard, recent studies suggest that analyzing the behaviour of some corporate governance variables in isolation may not be appropriate (Arellano \& Vallelado, 2008). Additionally, empirical evidence shows that the compensations of the executives are persistent over time. Based on model (2), a lagged-dependent variable is introduced and the result is the model (3). In this model, this study tests the hypothesis $\mathrm{H}_{03}$ by analysing the sign and the significance of the coefficient of the delayed dependent variable.

$$
\begin{aligned}
\ln \left(S_{\left.E P_{i, t}\right)}\right. & =\beta_{0}+\beta_{9} \cdot \ln \left(S_{E P_{i, t-1}}\right)+\beta_{1} \cdot P_{i, t}+\beta_{2} \cdot P_{i, t-1}+\beta_{3} \cdot \operatorname{SUBINDUSTRY}_{i, t} \\
& +\beta_{4} \cdot N E_{i, t}+\beta_{5} \cdot N E_{i, t}^{2}+\beta_{6} \cdot \ln (A T)_{i, t}+\beta_{7} \cdot \text { CREDIT }_{i, t} \\
& +\beta_{8} \cdot M A_{-} \operatorname{RISK}_{i, t}+\sum_{J=1}^{4} \lambda_{J} \cdot Y E A R_{t}+\eta_{i}+v_{i t}
\end{aligned}
$$

In model (3) it is assumed that the relationship between the compensations of executives in logarithms and the performance of the bank is linear. By following Leone et al. (2006), this study proposes model (4) in order to test the nonlinearity and the existence of asymmetry in the relationship between the variations in performance and SEP, depending on whether the company performances were better or worse than the previous year (hypothesis $\mathrm{H}_{01}$ ). 


$$
\begin{aligned}
\ln \left(\operatorname{SEP}_{i, t}\right) & =\beta_{0}+\beta_{9} \cdot \ln \left(\operatorname{SEP}_{i, t-1}\right)+\beta_{1} \cdot P_{i, t}+\beta_{2} \cdot P_{i, t-1}+\alpha_{1} \cdot P_{i, t} \cdot N_{i, t}+\alpha_{2} P_{i, t-1} \cdot N_{i, t-1} \\
& +\beta_{3} \cdot \operatorname{SUBINDUSTRY_{i,t}}+\beta_{4} \cdot N E_{i, t}+\beta_{5} \cdot N E_{i, t}^{2}+\beta_{6} \cdot \ln (A T)_{i, t} \\
& +\beta_{7} \cdot \operatorname{CREDIT}_{i, t}+\beta_{8} \cdot M A_{-} \operatorname{RISK}_{i, t}+\sum_{J=1}^{4} \lambda_{J} \cdot Y E A R_{t}+\eta_{i}+v_{i t}
\end{aligned}
$$

Where $\mathrm{N}_{\mathrm{i}, \mathrm{t}}$ is the dummy variable that indicates negative variations, respectively, in the performance of the i-th bank between two consecutive periods. That is:

$$
N_{i, t}=\left\{\begin{array}{lll}
0 & \text { si } & P_{i, t}-P_{i, t-1} \geq 0 \\
1 & \text { si } & P_{i, t}-P_{i, t-1}<0
\end{array}\right.
$$

This dummy variable is multiplied by the corresponding performance. In this way, equation (4) introduces two variables that reflect the negative variations in performance between the periods $\mathrm{t}-1, \mathrm{t}$ and $\mathrm{t}-2, \mathrm{t}-1$. Specifically, this study uses a characteristic (the sign of the variation in performance) to define the two regimes of behaviour, and in this way, it should improve the linear approximation.

In this context, the lag in the SEP is introduced as an explanatory variable, and this becomes related to the lag of the error term, so resulting in inconsistent estimates for both the within estimator and the first-difference estimator. An alternative method to avoid the discussed estimation problems for autoregressive models is to use an instrumental variable approach. Following the steps of Canarella and Nourayi (2008) and Lilling (2006), this study applied the GMM. Various forms of GMM estimators are feasible, depending on the definition of the conditions relative to the moments. Arellano and Bond (1991) proposed the GMM difference estimator. It takes advantage of all the conditions of lineal moments arising from the assumption of non-correlation with the error term.

Blundell and Bond (1998) demonstrated one of the limitations of this estimator by showing that if the autoregressive parameter is close to unity and there are few time periods, 
then simulations will produce estimates with a large bias in finite samples and coefficients that are imprecisely calculated. To overcome their weakness as instruments with variable lags at various levels, Arellano and Bover (1995) and Blundell and Bond (1998) proposed the system-GMM estimator. This estimator implies an additional restriction on the initial process conditions, so that all the available moments can be exploited through a system that uses lags in differences and levels of the dependent variable as instruments of the equation in levels and differences, respectively.

This article uses the system-GMM that has been implemented using a two-step estimator, so that estimates are efficient and asymptotically robust in the presence of heteroscedasticity. Additionally, standard second-stage error correction as proposed by Windmeijer (2005) for small samples is applied.

\section{RESULTS}

\section{Two-step GMM-system estimator}

In this section, the results have been obtained using the sample which is derived from the balanced panel, where data for five consecutive years for each bank is available. Arellano and Bond (1991) state that this is essential for testing errors are not second-order serial autocorrelation, condition necessary to ensure the robustness of the estimates.

Insert table 2 about here

Table 2 shows the results of the estimation of the system-GMM models (3) and (4) ${ }^{1}$. This section focuses directly on model (4b) because the variables that reflect the asymmetry are statistically significant. If only the contemporaneous year is considered, it appears that there is a positive relationship between SEP and performance. Furthermore, the pay-performance sensitivity is asymmetrical regarding the variation of the performance because whether the 
variation in the performance of the bank is positive there is greater sensitivity $\left(\beta_{1}=14.5783\right)$ to performance than when the variation is negative $\left(\beta_{1}+\alpha_{1}=3.3866\right)$. This difference in the pay-performance sensitivity depending on the sign of the variation of performance calls into question the role of the pay-performance incentives to align interest of executives and shareholders. This result supports the hypothesis $\mathrm{H}_{01}$ and is consistent with the managerial power theory, which states that executives may influence the pay-setting process in their own interests.

The findings show that the compensations of executives are affected by the current performance. However, surprisingly the direct influence on compensations of the performance of the previous period is not clear, therefore, this study cannot provide clear evidence regarding the hypothesis $\mathrm{H}_{02}$. It could mean that the executive has been motivated to make decisions based in the improvement of the immediate corporate performance.

The estimate of the coefficient for the lag of the variable dependent is 0.5391 and statistically significant. Thus, the hypothesis $\mathrm{H}_{03}$ is confirmed and, this study finds evidence in the sample examined that the executive compensation is persistent over time, which makes this variable depend on its own past.

Surprisingly, this study does not find enough evidence to support the idea that Spanish savings banks have more power over the board of directors to negotiate for higher pay than executive managers of commercial banks. Therefore, the results reject the hypothesis $\mathrm{H}_{04}$. It could be due to the limited and unbalanced sample of banks respect to savings banks of this study. Large samples of banks are clearly needed to test the robustness of this result.

The control variables generally show the expected sign although they are not statistically significant, with the exception of the variable size which is statistically significant and positively related to the executive pay. 


\section{Validation of the results}

The data used for the estimations in the previous sections is shown in nominal terms. However, this work has repeated the empirical study using data in real terms and the results are similar to those discussed above. To this end, the data for economic variables has been deflated using the general index of consumer prices published by the Spanish national institute of statistics with 2004 as the base year. The analysis has also been repeated using the methodology proposed by Arellano and Bover (1995) applied in unbalanced panel. The signs of the variables have not generally changed - and the values of the coefficients have not altered substantially ${ }^{2}$.

Additionally, Table 2 shows the joint statistical significance and validation of instruments for each regression. The Wald test was used in all the estimates to reject the null hypothesis that the variables are jointly equal to zero. The Hansen over-identification test was made on models (3) and (4) and revealed that this study cannot reject the null hypothesis of validity of the instruments being used to control the problem of endogeneity. Focusing on the autocorrelation test, this study cannot reject the null hypothesis that errors are not secondorder serial autocorrelation. These results do not reject the validity of the results of the empirical study.

\section{CONCLUSION AND DISCUSSION}

The recent controversy over the excessive executive pay associated with the corporate scandals and the financial crisis has called into a question the effectiveness of the executive incentive system to ensure that executives make decisions consistent with the shareholders' interest. In this context, this paper contributes to this debate by providing empirical evidence regarding the relationship between executive pay and corporate performance in the Spanish 
banking sector. In particular, the aim is to examine the pay-performance sensitivity depending on the sign of variation in bank performance.

From a theoretical point of view, this study expands the explanation of the managerial power theory which states that top executives may influence the pay-setting process to approve compensation schemes that are more favourable to executives than shareholders. In accordance with this reasoning, this study suggests that executives may have influence to change the pay-performance sensitivity in their own interests depending on the sign of the variation of the performance.

From a methodology perspective, the article discusses the novel use of GMM that controls endogeneity problems and is consistent with the presence of unobserved heterogeneity in each bank. Given the small sample size, this study additionally implements standard Windmeijer error correction.

The main results reveal that short executive pay is positively associated with contemporaneous corporate performance, as well as present an asymmetric relationship in terms of sensitivities. The asymmetry in the pay-performance sensitivity is greater when the variation in results is positive than when the variation of the results is negative. This result is consistent with the managerial power theory and calls into question the role of the payperformance incentives to align interest of executives and shareholders.

Regarding practical implications, the paper reveals that in spite of the numerous international recommendations in related to increase openness in executive compensation, there are numerous limitations in obtain public information about the compensations, mainly in long-terms executives pay and in individual terms, and without this information the shareholder and the rest of stakeholders can not control over excessive executive remuneration. Moreover, the results suggest that the board of directors and banking 
regulation should improve the supervision on the executive pay-setting process with the aim of ensuring that pay-performance incentive fulfills its purpose to align the interest of executive and shareholders.

This study has limitations that might open new areas for future research. The results of this study might be limited by the sample, the availability of information and the variables used in the empirical models. Future studies could move beyond Spanish savings banks and commercial banks to focus on cross-national studies to identify best practices and explore how context shapes managerial practices. In addition, the differences in incentive systems between Spanish savings banks and commercial banks could be further explored. To test the robustness of this study, future works should use more finely grained measurements of executive pay and could examine the non-linear relationship between performance and the four pay components: salary, bonus, equity participation and post-employment compensations. Moreover, this study could be extended to pay-volatility sensitivities which would be another fruitful avenue for new and interesting theoretical and empirical developments. Finally, this study encourages further research on the question whether the compensation structures in financial firms contributed to the instability, excessive risk-taking, and the most recent global financial crisis. 


\section{Notes}

\footnotetext{
${ }^{1}$ In order to give robustness to the results, model (4) is divided into (4a) which does not include the squared in the number of executives; and (4b) which has the same specification as the original model.

${ }^{2}$ The results using the deflated variables and the incomplete sample are not presented in the work, but are available to readers upon request.
} 


\section{REFERENCES}

Adams, R., \& Mehran, H. (2003). Is corporate governance different for bank holding companies?. Federal Reserve Bank of New York Economic Policy Review 9, 123-142.

Aebi, V., Sabato, G., \& Schmid, M. (2012). Risk management, corporate governance, and bank performance in the financial crisis. Journal of Banking \& Finance, 36(12), $3213-3226$.

Andres, P. de, \& Vallelado, E. (2008). Corporate governance in banking: The role of the board of directors. Journal of Banking \& Finance, 32(12), 2570-2580.

Arellano, M., \& Bond, S. (1991). Some tests of specification for panel data: Monte Carlo evidence and an application to employment equations. Review of Economics Studies, $58,277-297$.

Arellano, M., \& Bover, S. (1995). Another look at the instrumental variable estimation of error-component models. Journal of Econometrics, 68, 29-51.

B.C.B.S.: Basel Comitte on Banking Supervision (2004). Convergencia internacional de medidas y normas de capital. Banco de Pagos Internacionales, Basilea.

Barontini, R., \& Bozzi, E. (2011). Board compensation and ownership structure: empirical evidence for Italian listed companies. Journal of Management and Governance, 15, 59-89.

Bebchuk, L. A., \& Fried, J. M. (2004). Pay without performance: The unfulfilled promise of executive compensation. Cambridge, MA: Harvard University Press. 
Bebchuk, L. A., Fried, J. M., \& Walker, D. I. (2002). Managerial power and rent extraction in the design of executive compensation. University of Chacago Law Review, 69, 751846.

Blundell, R., \& Bond, S. (1998). Initial conditions and moment restrictions in dynamic panel data models. Journal of Econometrics, 87, 115-143.

Canarella, G., \& Nourayi, M.M. (2008). Executive Compensation and Firm Performance: Adjustment Dynamics, Non-linearity and Asymmetry. Managerial and Decision Economics, 29, 293-315.

CNMV (2008). Informe de Gobierno Corporativo de las entidades emisoras de valores admitidos a negociación en mercados secundarios oficiales. Ejercicio 2007. Comisión Nacional del Mercado de Valores, Madrid.

Comisión Conthe (2006). Código Unificado de Buen Gobierno, Informe del grupo especial de trabajo sobre buen gobierno de las sociedades cotizadas. Madrid.

Conyon, M.J., \& Schwalbach, J. (2000). Executive compensation: evidence from the UK and Germany. Long Range Planning, 33(4), 504-526

Core, J., Holthausen, R., \& Larcker, D. (1999). Corporate governance, chief executive officer, and firm performance. Journal of Financial Economics, 51, 371-406.

Crespí, R., García-Cestona, M. A., \& Salas, V. (2004). Governance mechanisms in Spanish banks. Does ownership matter?. Journal of Banking \& Finance, 28(10), 2311-2330.

Devers, C. E., Cannella, A. A., Reilly, G. P., \& Yoder, M. E. (2007). Executive compensation: A multidisciplinary review of recent developments. Journal of Management, 33(6), 1016-1072. 
Duffhues, P., \& Kabir, R. (2008). Is the pay-performance relationship always positive? Evidence from the Netherlands. Journal of Multinational Financial Management, 18, 45-60.

E.C.: European Commission (2009). Communication from the Commission accompanying Commission Recommendation complementing Recommendations 2004/913/EC and 2005/162/EC as regards the regime for the remuneration of directors of listed companies and Commission Recommendation on remuneration policies in the financial services sector. COM (2009) 211 final, Brussels, 30.4.2009.

E.C.: European Commission (2010). Green Paper: Corporate governance in financial institutions and remuneration policies. COM (2010) 284 final, Brussels, 2.6.2010.

Erkens, D., Hung, M., \& Matos, P. (2009). Corporate governance in the 2007-2008 financial crisis: Evidence from financial institutions worldwide. SSRN eLibrary. Retrived from http://ssrn.com/abstract=1397685

European Corporate Governance Forum (2009). Statement of the European Corporate Governance Forum on Director Remuneration. 23 March 2009. Retrived from http://ec.europa.eu/internal_market/company/docs/ecgforum/ecgfremuneration_en.pdf

Evans, J., \& Weir, C. (1995). Decision processes, monitoring, incentives and large firm performance in the UK. Management Decision, 33(6), 32-38.

Fahlenbrach, R., \& Stulz, R. M. (2011). Bank CEO incentives and the credit crisis. Journal of Financial Economics, 99(1), 11-26. 
Fama, E. F., \& Jensen M.C. (1983). Separation of ownership and control. Journal of Law and Economics, 26, 301-325.

Faulkender, M., Kadyrzhanova, D., Prabhala, N., \& Senbet, L. (2010). Executive compensation: An overview of research on corporate practices and proposed reforms. Journal of Applied Corporate Finance, 22(1), 107-118.

Galbreath, J. (2012). Are boards on board? A model of corporate board influence on sustainability performance. Journal of Management \& Organization, 18(4), 445-460.

García-Marco, T., \& Robles-Fernández, M. D. (2008). Risk-taking behaviour and ownership in the banking industry: The Spanish evidence. Journal of Economics and Business, $60(4), 332-354$.

Gibbons, R., \& Murphy, K. J. (1990). Relative Performance Evaluation for Chief Executive Officers. Industrial and Labor Relations Review, 43(3), 30-51.

Grifell-Tatjé, E. (2011). Profit, productivity and distribution: Differences across organizational forms-The case of Spanish banks. Socio-Economic Planning Sciences, $45(2), 72-83$.

Hanlon, M., Rajgopal, S., \& Shevlin, T. (2003). Are executive stock options associated with future earnings?, Journal of Accounting \& Economics, 36(1-3), 3-43.

Hansmann, H. (1996). The Ownership of Enterprise. Cambridge, MA: Harvard University Press.

Hau, H., \& Thum, M. (2009). Subprime crisis and board (in-) competence: private versus public banks in Germany. Economic Policy, 24(60), 701-752. 
Hilb, M. (2010). Redesigning corporate governance: lessons learnt from the global financial crisis. Journal of Management and Governance, 15, 533-538.

I.A.S.: International Accounting Standards IAS 11. (2003). Construction Contracts. Official Journal of the European Union. 13.10.2003., 54-183.

Iannotta, G., Nocera G., \& Sironi, A. (2007) . Ownership structure, risk and performance in the European banking industry. Journal of Banking \& Finance, 31, 2127-2149.

Jensen, M., \& K. J. Murphy (1990). Performance Pay and Top-Management Incentives. Journal of Political Economy, 98 (2), 225-64.

Jensen, M.C., \& Meckling W.H. (1976). Theory of the firm: Managerial behaviour, agency costs and ownership structure. Journal of Financial Economics, 3(4), 305-360.

John, K., \& Qian, Y. (2003). Incentive features in CEO compensation in the banking industry. Economic Policy Review, 9(1), 109-121.

Kaplan, S. N., \& Rauh, J. (2010). Wall Street and Main Street: What contributes to the rise in the highest incomes?. Review of Financial Studies, 23(3), 1004-1050.

Lee F., Lee T., \& Wu W. (2010). The relationship between human resource management practices, business strategy and firm performance: Evidence from steel industry in Taiwan, The International Journal of Human Resource Management, 21(9), 13511372

Leone, A., Shuang J., \& Zimmerman, J.L. (2006). Asymmetric sensitivity of CEO cash compensation to stock returns. Journal of Accounitng and Economics, 42, 167-192. 
Lilling M.S. (2006). The Link Between CEO Compensation and Firm Performance: Does Simultaneity Matter? . Atlantic Economic Journal, 34, 101-114.

Manzaneque, M., Merino, E., \& Banegas, R. (2011). Compensation levels of executive personnel in Spain: influence of the characteristics of the board of directors and of concentration of shareholdings. Innovar, 21(40), 107-126.

Minnick, K., Unal, H., \& Yang, L. (2011). Pay for performance? CEO compensation and acquirer returns in BHCs. Review of Financial Studies, 24(2), 439-472.

Murphy, K. J. (1985). Corporate Performance and Managerial Remuneration: An Empirical Analysis. Journal of Accounting and Economics, 7(1-3), 11-42.

Murphy, K. J. (1999). Executive compensation. Handbook of labor economics, 3, 2485-2563.

Novales, A. (2000). Econometría. Segunda Edición, McGraw-Hill, Madrid.

Nyberg, A. J., Fulmer, I. S., Gerhart, B., \& Carpenter, M. A. (2010). Agency theory revisited: CEO return and shareholder interest alignment. Academy of Management Journal, 53(5), 1029-1049.

Perry, T., \& Zenner, M. (2001). Pay for performance? Government regulation and the structure of compensation contracts. Journal of Financial Economics, 62, 453-488.

Royo, S. (2012). How Did the Spanish Financial System Survive the First Stage of the Global Crisis?. Governance. doi: 10.1111/gove.12000.

Sagarra, M., Mar-Molinero, C., \& García-Cestona, M. (2013). Spanish savings banks in the credit crunch: could distress have been predicted before the crisis? A multivariate 
statistical analysis. The European Journal of Finance. doi: 10.1080/1351847X.2013.784208

Sánchez-Marín, G., Baixauli-Soler, J.S., \& Lucas-Pérez, M.E. (2010). When much is not better? Top management compensation, board structure, and performance in Spanish firms. The International Journal of Human Resource Management, 21(15), 27782797.

Shin, T. (2013). Fair Pay or Power Play? Pay Equity, Managerial Power, and Compensation Adjustments for CEOs. Journal of Management, doi: 10.1177/0149206313478186

Shiwakoti, R. K. (2012). Comparative analysis of determinants of executive remuneration in the UK financial services sector. Accounting \& Finance, 52(1), 213-235.

Smallman, C., McDonald, G., \& Mueller J. (2010). Prologue: Governing the corporation: Structure, process and behaviour. Journal of Management \& Organization, 16, 194198.

Tien, C., Chen, C. N., \& Chuang, C. M. (2013). A study of CEO power, pay structure, and firm performance. Journal of Management \& Organization, forthcoming.

Van Essen, M., Otten, J., \& Carberry, E. J. (2012). Assessing managerial power theory: A meta-analytic approach to understanding the determinants of CEO compensation. Journal of Management, doi: 10.1177/0149206311429378

Vander Bauwhede H. (2009). On the relation between corporate governance compliance and operating performance. Accounting and Business Research, 39(5), 497-513

Windmeijer, F. (2005). A finite sample correction for the variance of linear efficient two-step GMM estimators. Journal of Econometrics, 126, 25-51. 
Zingales, L. (1998). Corporate Governance. The new Palgrave Dictionary of Economics and the Law., Editor P. Newman. 


\section{TABLES}

Table 1: Descriptive statistics

\begin{tabular}{|c|c|c|c|c|c|c|c|c|}
\hline \multicolumn{9}{|c|}{ (Unbalanced panel Obs. $=303, N=61, T=5)$} \\
\hline Variable & Obs. & Mean & S.D. & $25^{\text {th }} \mathbf{P}$ & $50^{\text {th }} P$. & $75^{\text {th }} \mathbf{P}$ & Skw. & Kurt. \\
\hline \multicolumn{9}{|c|}{ Executive compensation } \\
\hline $\begin{array}{l}\text { Short-term } \\
\text { pay }\end{array}$ & 256 & 295,216 & 348,053 & 139,347 & 177,347 & 286,264 & 3.561 & 17.535 \\
\hline Long-term pay & 162 & 60,655 & 119,084 & 6,300 & 15,222 & 68,375 & 5.582 & 44.343 \\
\hline \multicolumn{9}{|l|}{ Performance } \\
\hline $\begin{array}{l}\text { (Operating } \\
\text { Profits)/TA }\end{array}$ & 292 & 0.011 & 0.006 & 0.009 & 0.011 & 0.013 & 0.566 & 4.768 \\
\hline $\begin{array}{l}\text { (Alter Tax } \\
\text { Profits)/TA }\end{array}$ & 292 & 0.007 & 0.003 & 0.005 & 0.006 & 0.009 & 0.968 & 3.927 \\
\hline \multicolumn{9}{|c|}{ Entity characteristics } \\
\hline $\mathrm{TA}(\mathrm{mmll} €)$ & 292 & 32.600 & 64.300 & 5.250 & 10.700 & 24.800 & 3.741 & 18.176 \\
\hline CREDIT/TA & 292 & 0.818 & 0.083 & 0.766 & 0.829 & 0.866 & -0.892 & 5.208 \\
\hline $\mathrm{N}^{\mathrm{o}}$ Executives & 261 & 10.586 & 4.872 & 8.000 & 10.000 & 13.000 & 0.774 & 3.645 \\
\hline
\end{tabular}

\begin{tabular}{|c|c|c|c|c|c|c|c|c|}
\hline \multicolumn{9}{|c|}{ (Balanced panel Obs. $=195, N=39, T=5$ ) } \\
\hline Variable & Obs. & Mean & S.D. & $25^{\text {th }} \mathbf{P}$. & $50^{\text {th }} P$. & $75^{\text {th }} \mathrm{P}$. & Skw. & Kurt. \\
\hline \multicolumn{9}{|c|}{ Executive compensation } \\
\hline $\begin{array}{l}\text { Short-term } \\
\text { pay }\end{array}$ & 195 & 298,710 & 361,082 & 139,250 & 175,500 & 290,357 & 3.665 & 18.150 \\
\hline \multicolumn{9}{|l|}{ Performance } \\
\hline $\begin{array}{l}\text { (Operating } \\
\text { Profits)/TA }\end{array}$ & 195 & 0.010 & 0.005 & 0.008 & 0.010 & 0.013 & -0.451 & 5.595 \\
\hline $\begin{array}{l}\text { (Alter Tax } \\
\text { Profits)/TA }\end{array}$ & 195 & 0.007 & 0.003 & 0.005 & 0.006 & 0.008 & 0.823 & 4.043 \\
\hline \multicolumn{9}{|c|}{ Entity characteristics } \\
\hline TA (m.mll €) & 195 & 30.400 & 56.500 & 6.160 & 10.600 & 28.700 & 4.298 & 25.204 \\
\hline CREDIT/TA & 195 & 0.800 & 0.075 & 0.752 & 0.810 & 0.853 & -0.775 & 4.022 \\
\hline $\mathrm{N}^{\mathrm{o}}$ Executives & 195 & 10.923 & 4.779 & 8.000 & 10.000 & 13.000 & 0.925 & 3.890 \\
\hline
\end{tabular}

The table shows the descriptive statistics of the data included in unbalanced and balanced panel. 
Table 2: GMM-System estimator. Model (3) and (4)

\begin{tabular}{|c|c|c|c|}
\hline \multicolumn{4}{|c|}{$\begin{aligned} \ln \left(\operatorname{SEP}_{i, t}\right) & =\beta_{0}+\beta_{9} \cdot \ln \left(\operatorname{SEP}_{i, t-1}\right)+\beta_{1} \cdot P_{i, t}+\beta_{2} \cdot P_{i, t-1}+\alpha_{1} \cdot P_{i, t} \cdot N_{i, t}+\alpha_{2} P_{i, t-1} \cdot N_{i, t-1} \\
& +\beta_{3} \cdot \operatorname{SUBINDUSTRY} Y_{i, t}+\beta_{4} \cdot N E_{i, t}+\beta_{5} \cdot N E_{i, t}^{2}+\beta_{6} \cdot \ln (A T)_{i, t} \\
& +\beta_{7} \cdot \operatorname{CREDIT}_{i, t}+\beta_{8} \cdot M A_{-} \operatorname{RISK}_{i, t}+\sum_{J=1}^{4} \lambda_{J} \cdot Y E A R_{t}+\eta_{i}+v_{i t}\end{aligned}$} \\
\hline $\begin{array}{c}\text { Dependent Variable: } \\
\ln \left(\mathrm{SEP}_{\mathrm{i}, \mathrm{t}}\right)\end{array}$ & Model 3 & Model 4a & Model 4b \\
\hline $\ln \left(\operatorname{SEP}_{\mathrm{it}-1}\right)$ & $\begin{array}{l}0.5560 * \\
(0.2985)\end{array}$ & $\begin{array}{l}0.5368 * \\
(0.2667)\end{array}$ & $\begin{array}{l}0.5391 * * * \\
(0.1758)\end{array}$ \\
\hline$P_{i, t}$ & $\begin{array}{r}14.0343 \\
(8.8337)\end{array}$ & $\begin{array}{c}10.4059 * \\
(5.3397)\end{array}$ & $\begin{array}{l}14.5783 * * \\
(7.0232)\end{array}$ \\
\hline$P_{i, t-1}$ & $\begin{array}{l}-7.1305 \\
(9.8117)\end{array}$ & $\begin{array}{r}3.1943 \\
(10.7137)\end{array}$ & $\begin{array}{r}6.3467 \\
(10.5755)\end{array}$ \\
\hline $\mathrm{P}_{\mathrm{i}, \mathrm{t}} * \mathrm{~N}_{\mathrm{i}, \mathrm{t}}$ & & $\begin{array}{l}-7.2656^{* *} \\
(3.4549)\end{array}$ & $\begin{array}{l}-11.1917 * * \\
(5.0289)\end{array}$ \\
\hline $\mathrm{P}_{\mathrm{i}, \mathrm{t}-1} * \mathrm{~N}_{\mathrm{i}, \mathrm{t}-1}$ & & $\begin{array}{l}-6.3034 * * \\
(2.4737)\end{array}$ & $\begin{array}{l}-7.5095 * * \\
(2.9684)\end{array}$ \\
\hline SUBSINDUSTRY $_{\mathrm{i}, \mathrm{t}}$ & $\begin{array}{r}-0.0985 \\
(0.1026)\end{array}$ & $\begin{array}{r}-0.0930 \\
(0.0983)\end{array}$ & $\begin{array}{r}-0.0836 \\
(0.0672)\end{array}$ \\
\hline $\mathrm{NE}_{\mathrm{i}, \mathrm{t}}$ & $\begin{array}{r}-0.0355 \\
(0.0231)\end{array}$ & $\begin{array}{c}-0.0102 * \\
(0.0057)\end{array}$ & $\begin{array}{r}-0.0249 \\
(0.0193)\end{array}$ \\
\hline $\mathrm{NE}_{\mathrm{i}, \mathrm{t}}^{2}$ & $\begin{array}{l}0.0009 \\
(0.0009)\end{array}$ & & $\begin{array}{l}0.0006 \\
(0.0008)\end{array}$ \\
\hline $\ln (\mathrm{AT})_{\mathrm{it}}$ & $\begin{array}{l}0.1709 \\
(0.1146)\end{array}$ & $\begin{array}{l}0.1701 * * \\
(0.0821)\end{array}$ & $\begin{array}{l}0.1744 * * * \\
(0.0595)\end{array}$ \\
\hline CREDIT $_{\mathrm{i}, \mathrm{t}}$ & $\begin{array}{r}-0.4947 \\
(0.3867)\end{array}$ & $\begin{array}{r}-0.2986 \\
(0.4377)\end{array}$ & $\begin{array}{r}-0.2564 \\
(0.3377)\end{array}$ \\
\hline MA_RISK ${ }_{i, t}$ & $\begin{array}{l}0.1979 \\
(0.2406)\end{array}$ & $\begin{array}{l}0.2444 \\
(0.2871)\end{array}$ & $\begin{array}{l}0.2230 \\
(0.1911)\end{array}$ \\
\hline CONSTANT & $\begin{array}{l}2.2262 \\
(1.4344) \\
\end{array}$ & $\begin{array}{l}2.1006 \\
(1.8370) \\
\end{array}$ & $\begin{array}{l}1.9707 \\
(1.1917) \\
\end{array}$ \\
\hline $\begin{array}{l}\text { Explanatory variables } \\
\text { (test wald) }\end{array}$ & $\begin{array}{l}97.77 * * * \\
{[9,38]}\end{array}$ & $\begin{array}{l}84.00 * * * \\
{[10,38]}\end{array}$ & $\begin{array}{l}164.51 * * * \\
{[11,38]}\end{array}$ \\
\hline $\begin{array}{l}\text { Year dummy variables } \\
\text { (test wald) }\end{array}$ & $\begin{array}{c}0.86 \\
{[3,38]}\end{array}$ & $\begin{array}{c}2.72 * \\
{[3,38]}\end{array}$ & $\begin{array}{c}2.61 * \\
{[3,38]}\end{array}$ \\
\hline$F$ test & $\begin{array}{c}89.00 * * * \\
{[12,38]}\end{array}$ & $\begin{array}{l}67.92 * * * \\
{[13,38]}\end{array}$ & $\begin{array}{l}138.51 * * * \\
{[14,38]}\end{array}$ \\
\hline Hansen test $\chi^{2}$ & $\begin{array}{c}30.64 \\
{[36]} \\
\end{array}$ & $\begin{array}{c}24.15 \\
{[43]} \\
\end{array}$ & $\begin{array}{c}22.10 \\
{[44]} \\
\end{array}$ \\
\hline $\begin{array}{l}\mathrm{AR}_{1} \\
\mathrm{AR}_{2} \\
\end{array}$ & $\begin{array}{c}-1.78^{*} \\
0.93 \\
\end{array}$ & $\begin{array}{l}-2.00 * * \\
1.20 \\
\end{array}$ & $\begin{array}{l}-2.18 * * \\
1.01 \\
\end{array}$ \\
\hline
\end{tabular}

Te table reports the two-step GMM system estimator. The dependent variable is executive compensation $\left(\ln \left(\mathrm{SEP}_{\mathrm{i}, \mathrm{t}}\right)\right)$. Explanatory variables are: contemporary and first lag of performance $\left(\mathrm{P}_{\mathrm{i}, \mathrm{t}} \mathrm{P}_{\mathrm{i}, \mathrm{t}-1}\right)$, negative variations in performance between $\mathrm{t}-1, \mathrm{t}\left(\mathrm{P}_{\mathrm{i}, \mathrm{t}} * \mathrm{~N}_{\mathrm{i}, \mathrm{t}}\right)$, negative variations in performance between $\mathrm{t}-2, \mathrm{t}-1\left(\mathrm{P}_{\mathrm{i}, \mathrm{t}-\mathrm{1}} * \mathrm{~N}_{\mathrm{i}, \mathrm{t}-1}\right)$, ownership type(, SUBINDUSTRY $\left.{ }_{i, t}\right)$ and the control variables that measure: number of executives $\left(\mathrm{NE}_{\mathrm{i}, \mathrm{t}}\right)$, number of executives squared $\left(\mathrm{NE}_{\mathrm{i}, \mathrm{t}}^{2}\right)$ bank business $\left(\ln (\mathrm{AT})_{\mathrm{it},} \mathrm{CREDIT}_{\mathrm{i}, \mathrm{t}, \text { MA_RISK }}, \mathrm{R}_{\mathrm{i}, \mathrm{t}}\right)$

Standard errors with the robust adjustment for small samples proposed by Winddmeijer (2005) are in brackets. Statistically significant at $1 \%(* * *), 5 \%(* *)$ and $10 \%(*)$. 
